Araştırma Makalesi

\title{
Design based Investigation on Construction of Mathematical Modelling Problems: Example of Financial Content
}

\author{
Melike TURAL SÖNMEZ1 \\ 1 İstanbul Aydin University, Faculty of Education, Department of Science and Mathematics Education, mtural5@yahoo.com
}

\begin{tabular}{|c|c|}
\hline Article Info & Abstract \\
\hline $\begin{array}{l}\text { Received: } \quad \text { April 20, } 2017 \\
\text { Accepted: } \quad \text { August 14, } 2017 \\
\text { Online: } \quad \text { December 03, } 2017 \\
\text { Keywords: Design based research, } \\
\text { mathematical modelling, financial } \\
\text { literacy, mathematics education. }\end{array}$ & $\begin{array}{l}\text { The purpose of this study is to examine the construction of mathematical modelling } \\
\text { problems process in the content of financial literacy. It is also aimed to create design } \\
\text { proposals for construction of mathematical modelling problems. A design based } \\
\text { research method was used in this study. The participants were three seventh grade } \\
\text { students, six finance experts and nine mathematics education experts. Data collection } \\
\text { tools were transcription of video and tapes group discussions, presentations and } \\
\text { worksheets during mathematical modelling activities, and participant experts' } \\
\text { feedback form about mathematical modelling problems. There were three stages in } \\
\text { this study. First stage was application of preliminary study. This stage gave } \\
\text { information about convenience of problems to grade level, students' timing for } \\
\text { solution of problems, clarity of problems and students' background about content. In } \\
\text { second stage, finance experts commented on convenience of mathematical modelling } \\
\text { problems to financial literacy standards. In third stage, mathematics education } \\
\text { experts commented on convenience of problems to students' grade level, } \\
\text { mathematical modelling principles and seventh grade mathematics lesson objectives. } \\
\text { They also gave suggestion on progress. The frequency value of theme in feedback } \\
\text { forms was calculated and experts' expressions were given as citation. It was given } \\
\text { suggestion about stages and application of the design guide. }\end{array}$ \\
\hline
\end{tabular}

open access (a) CrossMark (c)

To cite this article: Tural Sönmez, M. (2017). Matematiksel modelleme problemlerinin yapılandırılması üzerine tasarım tabanlı inceleme: finansal içerik örneği. Journal of Computer and Education Research, 5 (10), 218-240. https://doi.org/10.18009/jcer.307314

\section{Matematiksel Modelleme Problemlerinin Yapılandırılması Üzerine Tasarım Tabanlı İnceleme: Finansal İçerik Örneği}

\begin{tabular}{|c|c|}
\hline Makale Bilgisi & Öz \\
\hline $\begin{array}{ll}\text { Geliş: } & \text { 20 Nisan } 2017 \\
\text { Kabul: } & 14 \text { Ă̆ustos } 2017 \\
\text { Yayın: } & \text { 03 Aralık } 2017 \\
& \\
\text { Anahtar } & \text { kelimeler: Tasarım } \\
\text { araştırması, } & \text { matematiksel } \\
\text { modelleme, finansal } & \text { okuryazarlık, } \\
\text { matematik eğitimi } & \end{array}$ & $\begin{array}{l}\text { Bu çalışmada yedinci sınıf seviyesinde finansal içerikte matematiksel modelleme } \\
\text { problemlerinin yapılandırma sürecinin incelenmesi amaçlanmıştır. Matematiksel } \\
\text { modelleme problemlerinin yapılandırılmasına yönelik tasarım önerisi oluşturulması } \\
\text { hedeflenmiştir. Araştırmada tasarım tabanlı araştırma yöntemi kullanılmıstır. } \\
\text { Çalışmanın katılımcları üç yedinci sınıf öğrencisi, altı finans uzmanı ve dokuz } \\
\text { matematik eğitimi uzmanından oluşmaktadır. Çalışmanın veri toplama araçları } \\
\text { yedinci sınıf öğrencilerinin matematiksel modelleme etkinlikleri süresinde } \\
\text { videolarının ve ses kaydının çözümlenmesi, öğrenci çalışma dokümanları, uzman } \\
\text { katılımcıların görüş alma formlarıdır. Çalışma üç aşamadan oluşmaktadır. Birinci } \\
\text { aşama ön uygulamanın yapılması aşamasıdır. Bu aşama, matematiksel modelleme } \\
\text { problemlerinin sınıf seviyesine uygunluğu, öğrencilerin zamanlamaları, problemlerin } \\
\text { anlaşılırlığı ve öğrencilerin bağlam hakkındaki bilgileri konusunda değerlendirmeler } \\
\text { sunmuştur. İkinci aşamada finans konusunda uzman kişilerden; matematiksel } \\
\text { modelleme problemlerinin finansal okuryazarlık standartlarına uygunluğu } \\
\text { konusunda görüş alınmıştır. Üçüncü aşamada ise matematik eğitimi uzmanları } \\
\text { matematiksel modelleme problemlerinin sınıf seviyesine, matematiksel modelleme } \\
\text { ilkelerine ve yedinci sınıf matematik dersi kazanımlarına uygunluğu konusunda } \\
\text { görüş bildirmişlerdir. Görüş alma formundaki maddelerin frekans değerleri } \\
\text { hesaplanmış ve uzmanların ifadelerinden alıntılar yapılmıştır. Araştırmada tasarım } \\
\text { rehberinin aşamalandırılmasına ve uvgulanmasına yönelik önerilerde bulunulmustur. }\end{array}$ \\
\hline
\end{tabular}


December 2017 Volume 5 Issue 10

www.joucer.com

http://dergipark.gov.tr/jcer

\section{Summary}

\section{Design based Investigation on Construction of Mathematical Modelling Problems: Example of Financial Content}

\section{Introduction}

Because of global financial crisis and personal financial needs, financial education issues have been discussed among authorities. Financial literacy has gained international recognition as a critical life skill for individuals. In this respect, many countries are developing financial education strategies and programmers. They introduce financial education into the school curriculum and designing dedicated learning frameworks. Because of short class hours, heavy content of lesson, lack of materials; integration of financial literacy subject in to curriculum is hard. Mathematics may provide a way for introducing financial topics. Especially mathematical modelling framework is convenient for it. Review of the literature shows that there is not enough information about application of mathematical modelling problems in financial contents. In addition to that there is a litle information about construction of mathematical modelling problems process. The purpose of this study is to examine the construction of mathematical modelling problems process in the content of financial literacy. Within the scope of this study, it is also aimed to create design proposals for construction of mathematical modelling problems.

In this direction, a design based research method was used in this study. The participants were three seventh grade students, six finance experts and nine mathematics education experts. Data collection tools were transcription of video and tapes group discussions, presentations and worksheets during mathematical modelling activities, and participant experts' feedback form about mathematical modelling problems.

Following Lesh \& Doerr (2003)'s conceptualization of mathematical modelling, six design principle were taken into consideration while the problems are preparing. Five mathematical modelling problems which written by researcher, were compatible with 
personal finance education standards, (The Jump \$tart Coalition National Standards in K-12 Personal Finance Education Standard, 2007), seventh grade mathematics objectives and financial literacy standards stated PISA (OECD, 2012).

There were three stages in this study. First stage was application of preliminary study. This stage gave information about convenience of problems to grade level, students' timing for solution of problems, clarity of problems and students' background about content. In second stage, finance experts commented on convenience of mathematical modelling problems to financial literacy standards. In third stage, mathematics education experts commented on convenience of problems to students' grade level, mathematical modelling principles and seventh grade mathematics lesson objectives. They also gave suggestion on progress. The frequency value of theme in feedback forms was calculated and experts' expressions were given as citation. Especially qualitative data in this study guided for improving mathematical modelling problems. It was given suggestion about stages and application of the design guide. 


\section{Giriş}

Günümüzde ekonomik fırsatların karmaşıklaşması ve bireysel finansal ihtiyaçların artması finansal okuryazarlık eğitimini gerekli kılmaktadır. Finansal okuryazarlık kavramının toplumdaki etkinliğini ve insanlar üzerindeki farkındalığını artırabilmek için ihtiyaçlara uygun finansal okuryazarlık eğitim programlarının geliştirilmesi önemlidir. İlgili literatür taramasına bakıldığında gelişen ve gelişmekte olan ülkelerde yapılan deneysel araştırmalar finansal eğitim alan kişilerin finansal eğitimi almayan bireylere göre birikim yapma, emekliliği planlama gibi finansal konularda daha başarılı olduklarını göstermiştir (Bernheim, Garrettand \& Maki, 2001; Cole \& Sampsonand, 2011; Lusardi, 2009). Bu gösterge finansal eğitimin finansal okuryazarlığı geliştirdiği ve bu yönde olumlu davranış değişikliği oluşturduğunu doğrulamaktadır. Ekonomik Kalkınma ve İşbirliği Örgütü (OECD) 2005 raporuna göre finans eğitimi okullarda olabildiğince erken yaşta başlamalıdır. Para yönetimi ile ilgili temel kavramların çocuklara öğretilmesi için en verimli zamanın on dört yaşın altında olduğu ifade edilmektedir. Buna neden olarak erken yaşlarda öğrenilen ve uygulanan finansal davranışların, yaşamın sonraki aşamalarında bireylerin finansal davranışlarını kalıcı olarak belirleyebileceği gösterilmektedir. Fakat seçmeli finans derslerinin konulması ya da finans eğitiminin okul programına entegresi yaygın programın yoğunluğu, konuya ilişkin materyalin ve zamanın yeterli olmaması, bu konuda uzman ve pedagojik materyallerin olmaması gibi nedenlerle süreci zorlaştırmaktadır (INFE, 2009). Bu anlamda finansal okuryazarlık derslerinin oluşturulmasından ziyade, derslere entegre edilebilecek finansal kazanımlar uygulama için alternatif oluşturmaktadır. Matematik ile finans alanlarının ortak yanları bulunduğu için finansal bağlamları ile matematik dersleri öğrenme ortamları için uygun durum oluşturabilmektedir.

Matematiğin gerçek hayatta kullanım alanlarını öğrencilere göstermek matematik eğitiminin en temel amaçlarından biridir. Matematik eğitimi programının bu hedefine ulaşmak için klasik anlamda oluşturulmuş sözel problemler ihtiyaca cevap verememektedir (Greer, 1993; Schoenfeld, 1982). Berry ve Hauston (1995), matematiksel modelleme problemlerinin gerçek dünyada karşılaşılan problemleri matematiksel olarak ifade etmede ve bu problemleri çözmede güçlü bir araç olduğunu belirtmişlerdir. Lesh ve Doerr'a (2003) göre modelleme, problem durumlarının zihinsel olarak düzenlenmesi, koordine edilmesi, sistemleştirilmesi ve organize edilerek bir örüntünün bulunması sürecidir. Matematiksel modellemede süreç önemlidir. Bu süreçte verilenlerin kullanılarak bir çözüme ulaşılması, çözümün gerçek hayat durumuyla karşılaştırılması, çözümün geliştirilmesi gibi döngüler bulunmaktadır (Zbiek \& Conner, 2006). Carlson, Larsen ve Lesh (2003) matematiksel model 
oluşturma etkinlikleri düzenlenirken altı öğretimsel prensibe dikkat edilmesi gerektiğini belirtmişlerdir. Bunlar: gerçeklik prensibi, model oluşturma prensibi, öz değerlendirme prensibi, model belgelendirme prensibi, yapıyı genelleme prensibi ve etkili prototip prensibidir.

Haines ve Crouch (2001) ile Haines Crouch ve Davis (2000) tarafından önerilen çoktan seçmeli test formatında hazırlanan matematiksel modelleme problemleri geniş kitleleri değerlendirmek için önemli ölçütler sunarken, açık uçlu soru formatı öğrencilerin problem çözme süreci ve öğrencilerin karar verme süreci hakkında önemli veriler sunmaktadır. Bu nedenle matematiksel modelleme problemlerinin açık uçlu olarak hazırlanması, öğrencilerin modelleme süreçleri ile ilgili detaylı veriler sağlanmasını kolaylaştırır. Matematiksel modelleme yeterliliklerinin ve becerilerinin ölçme ve değerlendirilmesine yönelik oldukça geniş bir literatür ve teorik yaklaşımlar olmasına rağmen (Crouch \& Haines 2004, Blomloj \& Jensen, 2003) açı uçlu matematiksel modelleme problemlerinin tasarlanmasına yönelik tasarım tabanlı bir çalışma yer almamaktadır.

Matematiksel modelleme konusu son zamanlarda alan araştırmacıları arasında en popüler konulardan biridir. Matematiksel modelleme konusunda birçok araştırma yapılmış olmasına rağmen, ortaokul ve lise seviyelerinde ve farklı bağlamlarda matematiksel modelleme etkinliklerine ihtiyaç duyulmaktadır (Aztekin \& Şener, 2015). Ortaokul seviyesinde finansal standartlar ve kazanımlar da dikkate alınarak öğrencilerin finansal okuryazarlıklarını ortaya çıkarmaya yönelik hazırlanmış matematiksel modelleme problemleri de literatürde bulunmamaktadır. Bu çalışmada finansal bağlamda matematiksel modelleme problemlerinin alana kazandırılması amaçlanmıştır. Ayrıca bu araştırma ile finansal içerikte matematiksel modelleme problemlerinin ön uygulama, uzman görüşü alma aşamalarında ne tür bilgileri açığa çıkardığını ve gerekli düzenlemeleri ve bu süreçlerin birbirinden farklılığı ortaya konmaktadır. Çalışma sonucunda uygulamalar ve katılımcıların görüşleri doğrultusunda matematiksel modelleme problemlerinin hazırlanmasına yönelik bir tasarım rehberi geliştirilmiştir.

\section{Yöntem}

\section{Araştırma Modeli}

Çalışmada yedinci sınıf seviyesinde finansal bağlamda matematiksel modelleme problemleri geliştirilmesi amaçlandığı için bu araştırma tasarım araştırması niteliğindedir. Tasarım, geliştirme ve uygulama süreçleri araştırmacılar ve katılımcılar ile gerçek uygulama ortamında işbirliği içinde yapılandırılır. Eğitim uygulamalarını iyileştirme amacıyla yapılması nedeniyle sistematik ve esnek bir araştırma yöntemidir (Wang \& Hannafin, 2005). 


\section{Çalışma Grubu}

Araştırmanın çalışma grubu üç yedinci sınıf öğrencisi, altı finans uzmanı ve dokuz matematik eğitimi uzmanından oluşmaktadır. Ön uygulamanın yapıldığı üç yedinci sınıf öğrencisi Ankara'da öğrenim görmektedir. Belirli finansal kazanımlara göre hazırlanan matematiksel modelleme problemleri iyi düzeyde matematiksel bilgi gerektirdiği için matematik dersinden karne notları 80 puanın üzerinde olan öğrencilerden rastgele seçim yapılmıştır. Bu öğrencilerden ikisi özel okula, biri devlet okuluna gitmektedir. Ailelerin sosyoekonomik durumları iyi düzeydedir. Finans alan uzmanlarından üçü finans konusunda doktora yapmakta, biri Türkiye Cumhuriyet Merkez Bankası'nda uzman olarak çalışmakta, ikisi finans üzerine yüksek lisans yapmış olup bankada çalışmaktadır. Matematik eğitimi uzmanlarından ikisi matematiksel modelleme konusunda doktora yapmaktadır. Diğer yedi kişi ise matematik eğitimi alanında öğretim üyesi olarak çalışmakta olup matematiksel modelleme konusunda çalışmaları bulunmaktadır.

\section{Veri Toplama Aracl}

Bu çalışmada veri toplama araçları problemlerin ön uygulaması esnasındaki video ve ses kayıtları, öğrenci çalışma dokümanları, matematik eğitimi alan uzmanı görüşü alma formu, finans alanı uzmanı görüş alma formundan oluşmaktadır.

\section{Matematiksel Modelleme Problemlerinin Hazırlanması ve Veri Toplama Süreci}

Problemlerin hazırlanması ve seçilmesi süreci üç aşamadan oluşmaktadır. Bu süreçler ön uygulamanın ardından değişikliklerin yapılması, finans uygulama alanı uzman görüşü analizinin yapılmasının ardından düzenlemelerin yapılması, finansal kazanımlara ve matematiksel kazanımlara uygunluk sınıf seviyesine uygunluk konusunda uzman görüşü analizinin ardından değişikliklerin yapılmasıdır. $\mathrm{Bu}$ aşamalardan sonra problemler geliştirilmiştir.

$\mathrm{Bu}$ çalışmada matematiksel modelleme bir araç olarak ele alınıp, Lesh ve Doerr 'in (2003) tanımladığı matematiksel modelleme tanımından yola çıkılarak, model oluşturma problemlerinin prensipleri ve modelleme problemlerinin aşamaları referans alınmıştır. Öncelikle literatürde mevcut olan finansal bağlamdaki modelleme problemleri incelenmiştir. Mevcut problemlerin yetersiz olması, yedinci sinıf seviyesine uygun olmaması gibi nedenlerden dolayı uygulama için araştırmacı tarafından beş adet finansal bağlamda matematiksel modelleme problemleri hazırlanmıştır. Modelleme problemleri hazırlanırken; bireysel finans eğitimi standartları (The Jump Start Coalition National Standards in K-12 Personal Finance Education Standard, 2007), yedinci sınıf matematik kazanımları (MEB, 2009) ve OECD tarafından hazırlanan "PISSA Finansal Okuryazarlık Standartları (OECD, 2012)" referans alınmıştır. 
Hazırlanan matematiksel modelleme etkinliklerinin Carlson, Lersen ve Lesh (2003)'in belirlediği modelleme etkinlikleri öğrenme prensiplerine, belirlenen yedinci sınıf matematik kazanımlara, finansal kazanımlara ve sınıf seviyesine uygun olması konusunda görüş alınmak üzere uzman görüş alma formu hazırlanmıştır. Ayrıca hazırlanan matematiksel modelleme problemlerinin bireysel finans standartlarına (The Jump Start Coalition National Standards, 2007) uygunluğu konusunda finans konusunda uzman kişilere sunulmak üzere de uzman görüş alma formu hazırlanmıştır.

Hazırlanan matematiksel modelleme problemlerinin öğrenci seviyesine uygunluğunu test etmek amaciyla, yedinci sınıfta öğrenim görmekte olan üç öğrenci ile ön uygulama yapılmıştır. Ön uygulama esnasında her bir matematiksel modelleme etkinliği yaklaşık 80 dakika sürmüştür. Öğrenciler problemleri üç kişilik grup halinde çözmüşlerdir. Bu süreçte öğrencilere herhangi bir yönlendirme yapılmamıştır.

Ardından, problemler finans konusunda uzman altı kişiye incelenmesi için gönderilmiştir. Daha sonra problemler, matematik eğitimi alanında uzman, modelleme konusunda araştırması olan dokuz kişiye incelenmesi için gönderilmiştir. Uzmanlar matematiksel modelleme problemleri görüş alma formlarını doldurmuşlardır.

\section{Uygulanan Matematiksel Modelleme Problemleri}

Meyve Bahçesi Problemi: Çiftçi Ahmet Bey'e babasından bir kenarı 40 metre olan kare şeklinde tarla miras kalmıştır. Ahmet Bey bu tarlayı meyve bahçesine dönüştürmeyi düşünmektedir. En uygun ağaç türü dikerek meyve bahçesi yatırımı yapmak için araştırma yapmaktadır. Araştırmaya tarlanın bulunduğu iklime ve coğrafyaya uygun olan ağaçların neler olduğu ile başlamıştır. Ardından bu ağaçların kaç yılda ürün verdiği, dikilecek ağaçların aralıklarının kaç metre olması gerektiği, bir ağaçtan ortalama kaç kg. meyve toplandığı, ürünün son beş yıldaki ortalama fiyatı ve ürünün iklim koşullarına uyumu gibi ulaştığı bilgiler verilmiştir. Ahmet Bey hesaplama yapmakta ve karar vermekte zorluk çekmektedir. Ahmet Bey'e en fazla gelir sağlayacak ağaç türünün hangisi olduğu konusunda yardımcı olunuz. Onu ikna etmek için yönteminizi ayrıntılı olarak açıklayan bir rapor yazınız.

Boya Problemi: Atahan Bey yeni taşınacağı 3+1 evi güzelleştirmek için iki odasını boyamak istiyor. Taşınacağı evin bu iki odasının renginde değişiklik yapacağı için her bir odaya 3 kat boya yapması gerekmektedir. Odaların kap1 ve pencerelerini ise boyamayacaktır. Atahan Bey odaların ebatlarını da düşünerek boya alacaktır. Her biri dikdörtgenler prizması şeklinde olan bu iki odanın ebatları verilmiştir. Edinilen bilgiye göre; 1 lt boya ile 8 metre karelik alanı bir kat boyanabilmektedir. Atahan Bey pazar araştırmasının ardından edindiği bilgiye göre kalite ve hesaplılık açısından bir markada 
karar kılmıştır. Bu ayki bütçesinden bu odaları boyamak için bu markanın litre ölçülerine göre en hesaplı seçimi yapacaktır. Edindiği bilgiye göre boyanın belirli ölçülerdeki litre fiyatları verilmiştir. Sizden istenen Atahan Bey'e yardımcı olmanızdır. Aşağıdaki sorular da göz önünde bulundurarak ayrıntılı bir rapor yazınız.

Evinin ebatlarına göre boyama için ne kadar boya gerekmektedir? Odaların ikisini de aynı renge boyamak istediğinde; hangi kutulardan seçmek daha hesaplıdır? Odaları farklı renklere boyamak; Atahan Bey'in boya için ayıracağı maliyetini etkiler mi? Etkiler ise nasıl?

Bisiklet Problemi: 2015 yılı bisiklet olimpiyatlarında birinci olan Çağan'ın 15 yaşındayken en büyük hobisi bisiklete binmekti. Bu nedenle bisiklet turnuvaları kulübüne üye olmuştu. Çağan, kulüpteki bisiklet turnuvalarında gruptan ayrılmayarak diğer kişilerle aynı hızda gidebilmesi için kaliteli bir bisiklet almak istemekteydi. Çağan 15 yaşındayken, bu nedenle amcasından 800 も borç alarak istediği bisikleti almıştı. Bugün 20 yaşında bir milli sporcu olan Çağan, maaş aldığı için amcasından aldığı bu parayı geri vermek istemektedir. Amcasının bu parayı geri vermesini kabul etmemesi üzerine; Çağan amcasına aynı değere karşılık gelen bir hediye almayı düşünmektedir. Fakat 5 yıl önce 800 も’nin bugün kaç も’ye denk geldiğini hesaplayamamaktadır. Sizin için genel fiyatlar düzeyini ölçen bazı ürünlerin 5 yıl önceki ve günümüzdeki etiket fiyatlarını bulduk. Çağan'ın amcasına borcunu ödemesi için, 5 yıl önceki 800 TL'nin satın alma gücünün bugün kaç TL'ye denk geldiğini bulması gerekmektedir. Çağan'a bu konuda yardımcı olunuz. Geliştirdiğiniz yöntemi ayrıntılı şekilde açıklayarak ona bir mektup yazınız.

Birikimini Değerlendir Problemi: 15 yaşındaki Hale üç sene boyunca bayram harçlıklarından, bursundan ve harçlığından 2000 も biriktirmiştir. Bu paraya üç sene boyunca hiç dokunmayarak 2013 yılından 2015 yılına kadar kumbarasında saklamıştır. Son üç yıl boyunca yıllık faiz, altın ve doların değişimi verilmiştir. Hale şu soruların cevaplarını merak etmektedir: Hale harçlığından artırdığı bu parayı farklı hangi şekilde/ şekillerde değerlendirseydi en fazla kazancı sağlamış olurdu? Hale 2013 ve 2015 tarihleri arasında en fazla getirisi olan yatırımı önceden öngörebilir miydi? Öngörebilseydi bu tahmini neye dayandırarak yapabilirdi? Hale parasının değerini yitirme riskini azaltmak için ne gibi önlemler alabilir? Bu konuda Hale'ye yukarıdaki sorulara cevap bulabileceği; parasını değerlendirmek isteyen her kişinin de faydalanabileceği bir mektup yazınız.

Sigorta Şirketi Problemi: Kasko işine yeni başlayan Tarık Bey, fiyatlandırma için sizden yardım istemektedir. Tarık Bey ehliyeti olan toplam 20000000 kişi ve kazaya karışan toplam 400000 kişiye ilişkin TÜİK Trafik Kaza İstatistikleri'ni sizin için bulup, ekte göndermiştir. İstatistikleri göz önünde bulundurarak trafik sigorta acentesi olan Tarık Bey'e kazaya karışan sürücü özelliklerinin fiyatlandırmada nasıl bir fiyatlandırma yapmalıdır? 
Ayrıca fiyatlandırma için model oluşturunuz. Bu fiyatlandırmanın gerekçesini hesaplarla birlikte anlatan, tüm sigorta şirketlerine örnek oluşturabilecek bir mektup yazınız.

\section{Veri analizi}

Matematiksel modelleme problemlerinin ön uygulaması süresinde öğrencilerin video ve ses kayıtları çözümlenmiş ve bu verilerden alıntılar yapılmıştır. Öğrenci çalışmaları incelenmiştir. Görüş alınan finans konusunda uzman kişi sayısı altı ve matematik eğitimi uzman sayısı dokuz olduğu için uzman görüşleri frekans değerleri belirtilmiş (Tablo1, Tablo 2, Tablo 3), ayrıca uzman görüşlerinden alıntılar yapılmıştır. Uzman görüşleri betimlenirken bayanlar için " $\mathrm{K}$ ", erkekler için " $\mathrm{E}$ " kodu kullanılmıştır. Geliştirilmesi gerektiği ifade edilen problemler, açıklamaları dikkate alınarak yeniden düzenlenmiştir.

\section{Geçerlilik ve güvenirlik}

Araştırmada uzman görüşlerinden alınan verilerin kapsam geçerlilik oranlarına bakılmıştır. Lawshe (1975) ve Veneziano ve Hooper'a (1997) göre kapsam geçerlik oranları p=0,05 anlamlılık düzeyinde 9 uzman için minimum KGO değeri 0.75, 6 uzman için ise 0.99 olmalıdır. Bu çalışmadaki kapsam geçerlilik oranları Tablo 1, 2, 3 ve 4' de gösterilmektedir.

Araştırmada matematik eğitimi alanında uzman bir öğretmen ve öğretim üyesinden oluşan bir geçerlik komitesi oluşturulmuştur. Araştırmanın tüm aşamalarında değişiklikler geçerlik komitesine danışılarak, onlardan onay alınarak gerçekleştirilmiştir. Ön uygulamadan elde edilen verilerin farklı açılardan sorgulama imkanı sağlanması için veri üçlemesi yapılmıştır. Çalışmada ses ve görüntü kayıtlarının çözümlenmesi, gözlem notları, öğrenci çalışmaları ve dokümanları gibi farklı veri kaynakları kullanılmış, temaların tutarlı bir şekilde doğrulanması için bütün veri toplama araçları birlikte değerlendirilmiştir (Creswell, 2003; Merriam, 1998; Miles \& Huberman, 1994). Bulgular doğrudan alıntılarla desteklenmiş, açık ve detaylı bir şekilde ortaya konulmuştur.

\section{Bulgular}

\section{Ön Uygulamanın Ardından Yapılan Düzenlemeler}

Ön uygulama hazırlanan matematiksel modelleme problemlerinin yedinci sinif öğrenci seviyesine uygunluğu, problemlerin anlaşılırlığı ve öğrencilerin bağlam hakkındaki ön bilgileri konusunda değerlendirmeler sunmuştur. Bu değerlendirmeler ardından şu değişiklikler yapılmıştır:

Hazırlanan problemlerin öğrencilere uygulanması yedinci sınıf seviyesine uygunluğu konusunda geri dönütler sağlamıştır. Buna örnek olarak "Meyve bahçesi" etkinliğinde gerçek hayatla uyumlu olması açısından bahçenin alanı dönüm cinsinden 
sorulmuştu. Uygulama esnasında öğrenciler karenin alanından karenin kenarını hesaplamakta güçlük çektiler. Bu süreçteki öğrenci ifadeleri şu şekildedir:

"Kare şeklinde 1,6 dönüm yani $1600 \mathrm{~m}^{2}$ tarladan bahsediliyor. Nasıl şekillendirebilirim bu tarlayı? Bir kenarı kaç m² olur ki? Nasıl hesaplanır? Hımmm..(Şekil 1'i gösterir)"

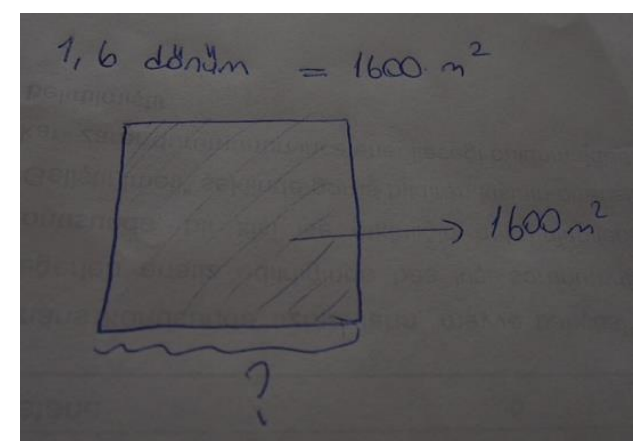

Şekil 1. Öğrencilerin meyve bahçesi problemindeki çizimleri

Öğrencilerin zorlanmasının sebebi karekök hesaplama konusunun sekizinci sınıf kazanımlarında mevcut olması olabilir. Bu nedenle kare şeklindeki tarlanın alanı yerine bir kenar uzunluğunun verilmesi uygun görülmüştür.

Hazırlanan problemlerin öğrencilere uygulanması problemlerin anlaşılırlığı konusunda geri dönütler sağlamıştır. Buna örnek durum "Sigorta şirketi" ve "Meyve bahçesi" probleminde gözlenmiştir. Sigorta şirketi probleminde ehliyeti olan toplam sürücü sayısı belirtilmeyip, sadece kazaya karışan sürücü sayıları verilmekteydi. Ön uygulama esnasında öğrencilerden Ahmet "kazaya karışan kadın sayısının kazaya karışan erkek sayısından az olması kafamı kurcalıyor, hıım buldum: kazaya karışan kadın sayısının daha az olmasının muhtemelen toplam kadın sürücü sayısının az olmasından kaynaklanıyor. Sadece kazaya karışan sürücü sayısı verisine dayandırarak modelleme yapmam hatalı olabilir." demiştir. Öğrencilerin verilerin yorum yapmak için yetersiz olduğunu belirtmesi üzerine etkinliğe ehliyeti olan toplam sürücü sayısı da dahil edilmiştir.

Ayrıca "Sigorta şirketi" probleminde verilerin orijinalinde Şekil 2'de görüldüğü gibi "sürücü belgesi sinıfı" bulunmaktaydı. Bu veride "bilinmeyen" ve "sürücü belgesi yok" ifadelerinin değerleri de bulunmaktaydı. Ön uygulamada bu verilerin nasıl değerlendirileceği öğrencilerde kafa karışıklığı oluşturduğu için bu veriler sorudan çıkartılmıştır. Konu ile ilgili öğrenciler arasında geçen diyalog şu şekildedir:

Murat: Tabloda "bilinmeyen" ve "sürücü belgesi yok" gibi veriler var. Bu da nereden çıktı.

Ahmet: Evet çok saçma veri. Sürücü belgesi bile yok ise nasıl kasko yapılacak.

Ayşe: Belirlenemeyen var bir de. Ne belirlenemiyor? Ne demek yani bu.. 


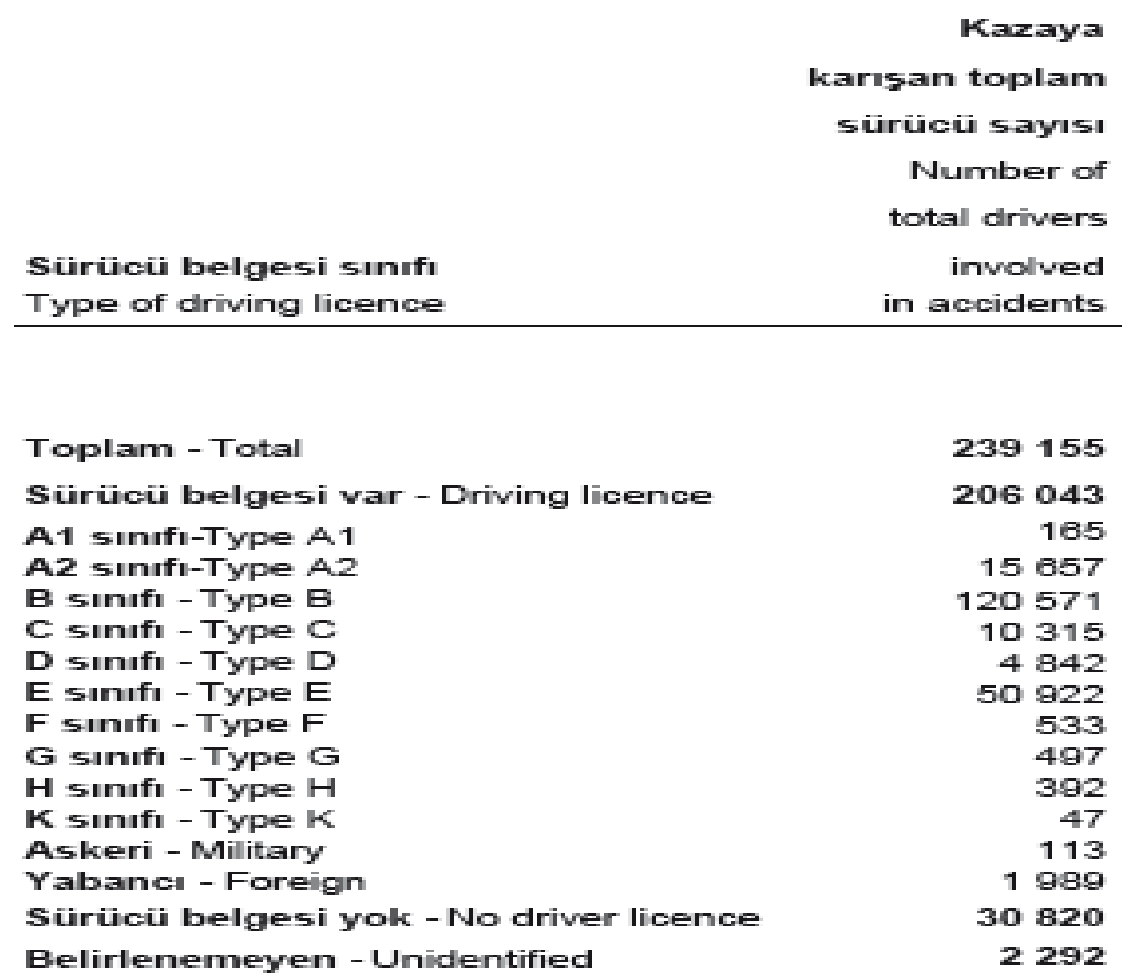

Şekil 2. Sigorta şirketi probleminde sürücü belgesi sınıfı ile ilgili gerçek veri

"Meyve bahçesi" etkinliğinde "ağacın iklim koşullarından etkilenme ihtimali" ifadesini öğrenciler yorumlayamamışlardır. Öğrenciler arasında geçen diyalog şu şekildedir:

Ahmet: Hımmm.. "ağacın iklim koşullarından etkilenme ihtimali" yazıyor tabloda. Ne demek bu şimdi?

Murat: İklim koşulları yağmurlu olabilir, karlı olabilir, sıcak olabilir A ğaçlar nasıl etkilenebilir?

Ayşe: Kuruyabilir ya da çok ürün verebilir.

Ahmet: Bu ifadeden bir şey anlamadım yine de. İhtimal kelimesi kafamı kurcalıyor.

Yukarıda geçen diyalogdan da anlaşıldığı gibi “ağacın iklim koşullarından etkilenme ihtimali" ifadesi öğrencilere karmaşık gelmiştir. Bu nedenle bu ifade "ağacın iklim koşullarına uyumu" şeklinde düzenlenmiştir.

Hazırlanan problemlerin öğrencilere uygulanması yedinci sınıf öğrencilerinin bağlam ile ilgili finansal bilgileri konusunda geri dönütler sağlamıştır. "Bisiklet" etkinliğinde ön uygulamada öğrenciler ürün fiyatı ile parça fiyatı arasında ilişkilendirme yapmışlardır. Ahmet' in ifadesi şu şekildedir:

"Bisiklet bir spor aletidir, verilerde spor aletinin yüzdesi ne kadar arttıysa o kadar artıralım" 


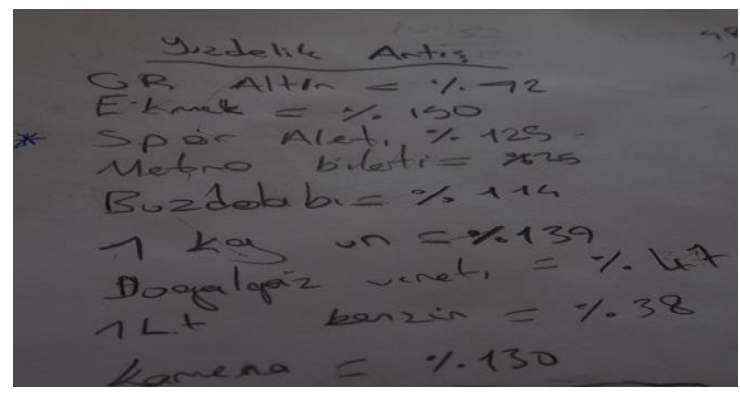

Şekil 3. Bisiklet probleminde öğrencilerin çözümleri

Ahmet'in bu önerisi üzerine problemde verilen ürün fiyatlarına birkaç spor aletinin fiyatı daha eklenerek problem geliştirilmiştir.

Finans Uygulama Alanı Uzman Görüşü Analizinin Yapılmasının Ardından Düzenlemeler

Hazırlanan matematiksel modelleme problemlerinin finansal eğitim standartlarında belirtilen kazanımlara (The Jump Start Coalition National Standards, 2007) uygunluğu konusunda finans konusunda uzman altı kişiden görüş alınmıştır. Uzmanlar problemler için finansal standartlara uygun, uygun değil ya da geliştirilmeli şeklinde, nedenleriyle birlikte görüş bildirmişlerdir. Görüşlerin frekans değerleri Tablo 1'de belirtilmiştir. Ayrıca uzmanların ifadelerinden alıntılar yapılmış, gerekli yerlerde sorularda düzenlemeler yapılmıştır. Son aşamada, tüm problemler için kapsam geçerlilik oranının 1 olması sağlanmıştır.

Tablo 1. Modelleme Problemlerinin Finansal Standartlara Uygunluğu Konusunda Uzman Görüşünün İlk Frekans Değerleri

\begin{tabular}{|c|c|c|c|c|}
\hline & \multicolumn{3}{|c|}{ Finansal Standartlara Uygunluk } & Kapsam geçerlilik \\
\hline Problem /Uygunluk & $\operatorname{Uygun}(f)$ & Uygun Değil(f) & Geliştirilmeli(f) & $\begin{array}{c}\text { oranlart } \\
(K G O)\end{array}$ \\
\hline Meyve Bahçesi & 5 & 0 & 1 & 0.67 \\
\hline Boya & 6 & 0 & 0 & 1 \\
\hline Bisiklet & 5 & 0 & 1 & 0.67 \\
\hline Sigorta Şirketi & 5 & 0 & 1 & 0.67 \\
\hline Birikimini değerlendir & 5 & 0 & 1 & 0.67 \\
\hline
\end{tabular}

Finans konusunda uzmanların "meyve bahçesi" etkinliği hakkındaki fikirleri frekans değerleri analiz edildiğinde beş kişi etkinliğin finansal kazanımlara uygun olduğu konusunda, bir kişi ise etkinliğin geliştirilebileceği konusunda görüş belirtmiştir. "Geliştirilmeli" şeklinde görüş bildiren kişinin önerisinde "Bir ağacın ortalama kaç yıl yaşadığı" sütundaki bilgilerin insan ömrünün üzerinde olması konusunun iktisadi öneminin olduğu vurgulanmıştır. Konuya ilişkin görüş şu şekilde belirtilmiştir:

“A ğaçlarnn yaşı bir insan ömrünün üzerinde olduğundan gelecek nesline mirasçılarnna bunu bırakmasının kişinin kendi faydasına ne kadar etkisi olduğu, iktisatta bunu kullanıyoruz." E2 
Meyve bahçesi matematiksel modelleme etkinliğinde problemin finansal olarak da değerlendirilmesi istendiği için öğrencilerin bu durumu da tartışmaları istenilmiştir. Bu nedenden dolayı probleme ağaçların ortalama yaşam süreleri ile ilgili veri eklenmiştir.

Bisiklet etkinliğine ilişkin beş uzman problemin finansal kazanımlara uygun olduğu konusunda, bir kişi ise problemin geliştirilebileceği konusunda görüş belirtmiştir. "Geliştirilmeli" şeklinde görüş bildiren kişinin önerilerinin birinde "ürünler" ifadesi yerine "genel fiyatlar düzeyini ölçen ürünlerin" ifadesi kullanımı önerilmiştir. Konuya ilişkin görüş şu şekilde belirtilmiştir:

"Bu ifade yerine, "enflasyon hesaplamasinda kullanılan ürünlerin" veya enflasyon ifadesi kullanılmak istenmiyorsa, "genel fiyatlar düzeyini ölçen ürünlerin" ifadesi kullanılabilir mi? O zaman tablo daha anlamlı olur." K1

Problem kökünde geçen ürünler ifadesinin kullanımında öneri dikkate alınarak ifade düzenlenmiştir. Ayrıca problemin içeriğine ilişkin ürünlerin bütçe içindeki payları bir sütun halinde verilerek öğrencilerin ağırlıklandırma yapmalarının daha bilimsel olduğu belirtilmiştir. Konuya ilişkin görüş şu şekilde belirtilmiştir:

"Her bir ürünün bütçe içindeki payı/ağırlığı farklıdır. Örneğin, her gün ekmek alırız, ama her gün spor aleti almayız. Dolayısıyla, ürünlerin ağırlıklarına dair bir sütun eklenebilir mi? Böylece, uygun görülürse, çocuklar, çarpma ve ağırlıklandırma açısından da matematik kazanımı elde etmiş olacaktır. TCMB aylık fiyat gelişmeleri bülteninde en son sayfada temel harcamaların ağırlıklarına dair bir tablo var, oradan fikir edinilebilir. 'http://www.tcmb.gov.tr/wps/wcm/connect/0dc701664074-4502-b77d

c79694ce594b/afiyatkasim15.pdf?MOD=AJPERESECACHEID=ROOTWORKSPACE0dc701664074-4502-b77d-c79694ce594b"K1

Önerinin bilimsel açıdan doğru olmasına rağmen önerilen bu değişikliğin yapılması durumunda problem yedinci sınıf öğrencilerinin seviyelerinin üzerinde olacağından alan uzmanı görüşüne sunulmuştur. Alan uzmanı görüşü sonucunda etkinliğe ilişkin bu öneride bir değişiklik yapılmamasına karar verilmiştir.

Bisiklet etkinliğinde tabloda verilen ürünler arasında bisiklet yapımında kullanılan malzemelerin bulunması önerilmiştir. Konuya ilişkin görüş şu şekilde belirtilmiştir:

"Tüketici sepetinin içinde bisikletle alakah birkaç kalemin de olması gerekir diye düşünüyorum. Jant ya da lastik fiyatı gibi."E2

$\mathrm{Bu}$ öneri üzerine fiyatı verilen ürünlere lastik ve jant fiyatının eklenmesine karar verilmiştir.

Finans konusunda uzmanların "sigorta şirketi" etkinliği hakkındaki fikirleri frekans değerleri analiz edildiğinde bir kişi ise etkinliğin geliştirilebileceği konusunda görüş 
belirtmiştir. "Geliştirilmeli" şeklinde görüş bildiren kişinin önerisinde problemde trafik sigortası ya da kasko şeklinde netleştirilmesi önerilmektedir. Konuya ilişkin görüş şu şekilde belirtilmiştir:

“Trafik sigortası zorunlu olarak yaptırılan bir sigortadır. Yaptırılmazsa, cezası vardır. Ayrıca dileyen kasko da yaptırabilmektedir. Hangisi kast ediliyor burada? Öte yandan, sorunun eğitimsel amacı çerçevesinde bu ayrımı yapmak önemli midir, bilmiyorum." K1

Öneri doğrultusunda "trafik sigortası" ifadesi yerine "kasko" ifadesi kullanılması uygun görülmüştür.

"Birikimini değerlendir" etkinliğinde bir kişi problemin geliştirilebileceği konusunda görüş belirtmiştir. "Geliştirilmeli" şeklinde görüş bildiren kişinin önerisinde "Halenin parası 2015 yılı sonunda en fazla ne kadar olurdu?" problemin hesaplanmasının içeriğe ve finansal kazanıma uygun olmadığı belirtilmiştir. Konuya ilişkin görüş şu şekilde belirtilmiştir:

"Paranın değerlendirilmesi için seçenek çok fazla. Tabloda yer alan dört alternatiften sadece birine yatırabilir veya parasını bu alternatifler arasında bölüştürerek sepet yapabilir. Dolayısıyla bu sorunun cevabı için çok fazla alternatif hesaplanması gerekir. Bana pek uygun bir soru gibi gelmedi. Alternatif olarak, tabloya enflasyon eklenirse, birikiminin yatırım yapmadı̆̆ı için ne kadar azaldığı sorusu eklenebilir." K1

$\mathrm{Bu}$ yoruma ilişkin; modelleme problemlerinin alternatif çözümler içerebilmesi durumu düşünüldüğünde çözüm alternatiflerini öğrencilerin tartışması yorumlaması açısından uygun bir problem olduğu düşünülmüştür. Bu açıdan problem kökü "Hale harçlığından artırdığı bu parayı farklı hangi şekilde/ şekillerde değerlendirseydi en fazla kazancı sağlamış olurdu?" şeklinde düzenlenmiştir.

Modelleme Prensiplerine Uygunluk Konusunda Uzman Görüşü Analizinin Ardından Değişikliklerin Yapılması

Hazırlanan matematiksel modelleme problemlerinin Carlson, Lersen ve Lesh (2003)'in belirlediği model oluşturma problemleri öğrenme prensiplerine uygun olmasi konusunda dokuz akademisyenden görüş alınmıştır. Uzmanlar problemler için modelleme prensiplerine uygun, uygun değil ya da geliştirilmeli şeklinde nedenleriyle birlikte görüş bildirmişlerdir. Görüşlerin frekans değerleri Tablo 2 ve Tablo 3 'de belirtilmiştir. Tabloda belirtilen ' $U$ ' sembolü tablonun üstünde belirtilen prensibe uygun olduğunu, ' $G$ ' sembolü tablonun üstünde belirtilen prensibin geliştirilebileceği, ' $\mathrm{D}$ ' sembolü ise tablonun üstünde belirtilen prensibe uygun olmadığını belirtmektedir. Ayrıca uzmanların ifadelerinden alıntılar yapılmıştır. 
Tablo 2. Modelleme Problemlerinin Gerçeklik, Model oluşturma, özdeğerlendirme prensipleri Uygunluğu Konusunda Uzman Görüşünün Frekans Değerleri

\begin{tabular}{|c|c|c|c|c|c|c|c|c|c|c|c|c|}
\hline \multicolumn{13}{|c|}{ Modelleme Prensipleri (Gerçeklik, model oluşturma, özdeğerlendirme prensipleri) } \\
\hline & & ŗ̧ek & & $K G O$ & $M$ Mod & olu & $r m a$ & KGO & $\ddot{O} z a$ & erle & & KGO \\
\hline Problemler & $\mathrm{U}$ & $\mathrm{D}$ & G & & $\mathrm{U}$ & $\mathrm{D}$ & $\mathrm{G}$ & & $\mathrm{U}$ & $\mathrm{D}$ & $\mathrm{G}$ & \\
\hline Meyve Bahçesi & 8 & 0 & 1 & 0.78 & 8 & 0 & 1 & 0.78 & 9 & 0 & 0 & 1 \\
\hline Boya & 8 & 0 & 1 & 0.78 & 9 & 0 & 0 & 1 & 8 & 0 & 1 & 0.78 \\
\hline Bisiklet & 8 & 0 & 1 & 0.78 & 9 & 0 & 0 & 1 & 9 & 0 & 0 & 1 \\
\hline Sigorta Şirketi & 8 & 0 & 1 & 0.78 & 8 & 0 & 1 & 0.78 & 9 & 0 & 0 & 1 \\
\hline Birikimini değerlendir & 9 & 0 & 0 & 1 & 8 & 0 & 1 & 0.78 & 9 & 0 & 0 & 1 \\
\hline
\end{tabular}

Tablo 3. Modelleme Problemlerininin Model belgelendirme, yap genelleme ve etkili prototip prensiplerine Uygunluğu Konusunda Uzman Görüşünün Frekans Değerleri

\begin{tabular}{|c|c|c|c|c|c|c|c|c|c|c|c|c|}
\hline \multicolumn{13}{|c|}{ Modelleme Prensipleri (Model belgelendirme, yapt genelleme ve etkili prototip prensipleri) } \\
\hline \multirow[b]{2}{*}{ Problemler } & \multicolumn{3}{|c|}{ Model belgelendirme } & \multirow[t]{2}{*}{ KGO } & \multicolumn{3}{|c|}{ Yapıyı genelleme } & \multirow[t]{2}{*}{ KGO } & \multicolumn{3}{|c|}{ Etkili prototip } & \multirow[t]{2}{*}{ KGO } \\
\hline & $\mathrm{U}$ & $\mathrm{D}$ & G & & $\mathrm{U}$ & $\mathrm{D}$ & G & & $\mathrm{U}$ & $\mathrm{D}$ & G & \\
\hline Meyve Bahçesi & 9 & 0 & 0 & 1 & 9 & 0 & 0 & 1 & 9 & 0 & 0 & 1 \\
\hline Boya & 8 & 0 & 1 & 0.78 & 8 & 0 & 1 & 0.78 & 8 & 0 & 1 & 0.78 \\
\hline Bisiklet & 9 & 0 & 0 & 1 & 9 & 0 & 0 & 1 & 9 & 0 & 0 & 1 \\
\hline Sigorta Şirketi & 9 & 0 & 0 & 1 & 9 & 0 & 0 & 1 & 9 & 0 & 0 & 1 \\
\hline Birikimini değerlendir & 8 & 0 & 1 & 0.78 & 8 & 0 & 1 & 0.78 & 8 & 0 & 1 & 0.78 \\
\hline
\end{tabular}

"Meyve bahçesi" etkinliğinde uzmanlardan biri problemin gerçeklik ve model oluşturma prensiplerine uygunluğunun geliştirilebileceği konusunda görüş bildirmişlerdir. Konuya ilişkin görüş şu şekilde belirtilmiştir:

"Modelleme ilkelerinin gerçeklik prensibine uygunluğu açısından "bir kenarı 40 metre olan" ifadesi yerine "1,6 dönüm" ifadesi daha uygun olabilir." K5

Ön uygulamada soruda " $\mathrm{m} 2$ " birimi yerine öneride ifade edildiği gibi "dönüm" birimi yer almaktaydı. Fakat uygulamada yedinci sınıf öğrencileri alandan kenarı bulmakta zorluk çekmişlerdir. Kazanımlar incelendiğinde karekök hesaplamalarının sekizinci sınıfta bulunduğundan problemde bu öneriye ilişkin bir değişiklik yapılmamıştır.

"Boya" etkinliğinde uzmanlardan biri ise etkinliğin gerçeklik, öz değerlendirme, model belgelendirme, yapıyı genelleme ve etkili prototip prensiplerine uygunluğunun geliştirilebileceği konusunda görüş bildirmişlerdir. Öncelikli olarak problemde "en hesaplı şekilde boya seçimi" ifadesine ilişkin bazı önerilerde bulunulmuştur. Konuya ilişkin görüş şu şekilde belirtilmiştir:

"En hesaph şekilde boya seçimi" yerine bir marka ismi verilebilir. Soruda geçen ifade "bu seçilmiş bir markanın en hesaplı seçimi.." şeklinde düzenlenebilir."K5

"Boya kalitesi göz ardı ediliyor mu? " E8

$\mathrm{Bu}$ önerilere ilişkin finansal ilkelere de sadık kalmak için marka ismi vermeden problem düzenlenmiştir. Uzmanlardan ikisi boya etkinliğinin tek çözümünün olması konusunda bazı değerlendirmelerde bulunmuşlardır. Bunlar:

“Yalnızca mali açıdan düşünüldüğünde tek çözüm mü (en iyi çözüm) olur?"E8 
"Bence bu problemde çözüm yolu tek (birim boya miktarnı bulacak, duvarlarn da boyanacak yüzölçümünü bularak, 8'e bölecek, 3 kat olduğu için üçle çarpacak, en ucuzdan şu kadar lt demesi yeterli) Problem karmaşık ama beklenen yol belli. Bu bakımdan, farklı model oluşturmaya izin vermiyor gibi. Değiş̧kenler birbiriyle ilişkili olmadığı için, sadece çok işlem gerektiren zor bir problem gibi geldi bu bana. "K7

İkinci ve üçüncü maddelerde problem kökünde belirtilen “Odaların ikisini de aynı renge boyamak istediğinde; hangi kutulardan seçmek daha hesaplıdır?" "Odaları farklı renklere boyamak; Atahan Bey'in boya için ayıracağı maliyetini etkiler mi? Etkiler ise nasıl?" sorularında farklı kombinasyonlar yaplarak finansal yorumlar farklılık gösterebilir. Bu nedenle etkinliğe ilişkin bir değişiklik yapılmamasına karar verilmiştir.

"Bisiklet" etkinliğinde uzmanlardan bazıları etkinliğin gerçeklik prensibine uygunluğunun geliştirilebileceği konusunda görüş bildirmişlerdir. Uzman görüşleri şu şekildedir:

“Bence çok iyi bir problem olmuş. Ama Türk kültürüne uygun mu bilemedim. Dedesi o borcu geri almaz, Türk adetlerine yakışmaz. Gerçeklik prensibinde şüpheli yaklaştım." K7

"Yabancı kültürlerde olabilir ama Türkiye de hiç bir dede bu paranın (borç bile diyemiyorum) ödenmesini istemez" E8

"Türk toplumunda dedeler borç vermez hediye ederler." K9

$\mathrm{Bu}$ eleştirilere ilişkin problemdeki ifadeler gerçekçi olacak şekilde güncellenmiştir. "Sigorta şirketi" etkinliğinde uzmanlar etkinliğin gerçeklik ve model oluşturma prensiplerine uygunluğunun geliştirilebileceği konusunda görüş bildirmişlerdir. Sigorta şirketi etkinliğine ilişkin tartışma sorularına kazaya karışan sürücü sayısına vurgu yapmak için bazı sorular eklenebilir şeklinde öneride bulunulmuştur.

"Kazaya karışan sürücü sayısına vurgu yapmak için" Sence kimler daha çok kaza yapıyor? gibi sorular sorulabilir." K5

$\mathrm{Bu}$ öneriye ilişkin tartışma sorularına önerilen bu sorular eklenmiştir. Sigorta şirketi etkinliğinde soru kökünün anlaşılmasına ilişkin bazı eleştirilerde bulunulmuştur. Bunlar:

“Bence bu modelleme etkinliğinin problem durumu iyi anlaşılmıyor. Türkçesi düzenlenmeli Belki de sadece nasıl bir fiyatlandırma yapmalıdır? Şeklinde direkt sormalısın." K7

" "Kriter" mi "kriterler mi?" "E8

Öneriler dikkate alınarak problem kökünde yer alan ifadeler düzenlenmiştir. “Birikimini değerlendir" etkinliğinde etkinliğin model oluşturma, model belgelendirme, yapıyı genelleme ve etkili prototip prensiplerine uygunluğunun geliştirilebileceği konusunda görüş bildirilmiştir. Öneride tek çözüm üzerinde durulmuştur. Uzman ifadesi şu şekildedir: 


\section{“Tek çözüm yok mu?" E8}

Problemin çözümünde finans uzmanının da "Paranın değerlendirilmesi için seçenek çok fazla. Tabloda yer alan dört alternatiften sadece birine yatırabilir veya parasını bu alternatifler arasında bölüştürerek sepet yapabilir." şeklinde belirttiği gibi, problemin birçok çözümü bulunmaktadır. Öğrencilerin bu ihtimalleri öngörebilmeleri ve sepet yapma fikirleri önemsenmektedir. Bu nedenle eleştiri üzerine bir düzenleme yapılmamıştır.

Uzmanlardan biri tüm problemlere yönelik mektup yazımına ilişkin bir eleştiride bulunmuştur. Öneri şu şekilde belirtilmiştir.

“Tüm problemler mektupla sonlanıyor. İfadesi en kolay olduğu için biz de bir araştırmamızda mektubu kullanmıştık ama arada poster oluşturma, akış-bağlantı şeması çizme, vs gibi beklentilerimiz de olmuştu. Hem yapı belgelendirme prensibini de güçlendirmiş olursun. " K6

Bu eleştiriye yönelik meyve bahçesi ve boya problemlerinin problem kökünde "Onu ikna etmek için yönteminizi ayrıntılı olarak açıklayan bir rapor yazınız." şeklinde ifade değişikliği yapılmıştır. Ayrıca; yapı belgelendirme prensiplerini güçlendirmek için uygulama esnasında vakit kalırsa öğrencilere sunum yaptırılması kararlaştırılmıştır.

Matematik eğitimi üzerine uzman dokuz kişiden etkinliklerin matematik kazanımlarına uygunluğu ve sınıf seviyesine uygunluğu konusunda görüş alınmıştır (Tablo $4)$.

Tablo 4. Modelleme Problemlerin Kazanımlara, Sınıf Seviyesine Uygunluğu Konusunda Uzman Görüşünün Frekans Değerleri

\begin{tabular}{|c|c|c|c|c|c|c|c|c|}
\hline \multirow[b]{2}{*}{ Problem/Uygunluk } & \multicolumn{3}{|c|}{ Kazanımlara uygunluk } & \multirow[t]{2}{*}{ KGO } & \multicolumn{3}{|c|}{ Sinıf seviyesine uygunluk } & \multirow[t]{2}{*}{ KGO } \\
\hline & $u$ & $D$ & $G$ & & $U$ & $D$ & $G$ & \\
\hline Meyve Bahçesi & 9 & 0 & 0 & 1 & 9 & 0 & 0 & 1 \\
\hline Boya & 9 & 0 & 0 & 1 & 9 & 0 & 0 & 1 \\
\hline Bisiklet & 9 & 0 & 0 & 1 & 8 & 0 & 1 & 0.78 \\
\hline Sigorta Şirketi & 9 & 0 & 0 & 1 & 8 & 0 & 1 & 0.78 \\
\hline Birikim değerlendir & 9 & 0 & 0 & 1 & 9 & 0 & 0 & 1 \\
\hline
\end{tabular}

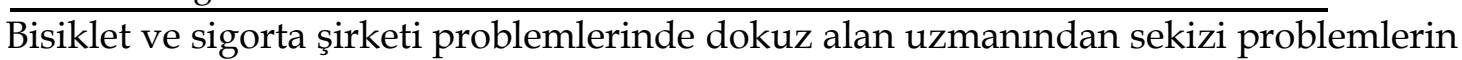
sınıf seviyesine uygun olduğunu belirtmiş, biri ise bu problemlerin sınıf seviyesine uygunluğunun geliştirebileceğini belirtmiştir (Tablo 4). Alan uzmanı görüşünü şu şekilde belirtmiştir:

“Bisiklet ve sigorta şirketi soruları öğrenciler için zor olabilir mi? Fazlaca detay var."E8

$\mathrm{Bu}$ problemlerin ön uygulaması yapıldığında öğrenciler problemi anlamakta, detayları analiz etmekte zorluk çekmedikleri için problemde bir değişiklik yapılmamasına karar verilmiştir.

\section{Tartışma ve Sonuç}

İlköğretim ve ortaöğretim seviyesinde ve çeşitli bağlamlarda matematiksel modelleme çalışmalarına ihtiyaç duyulmaktadır (Aztekin \& Şener, 2015). Günümüzde önemi 
artan finansal okuryazarlık kavramlarının matematik derslerine matematiksel modelleme problemleri ile entegre edilmesi örnek bir uygulamadır. Literatür taramasında, özel olarak bu amaca yönelik hazırlanmış sınıf seviyesi, matematiksel modelleme ilkeleri ve finansal kazanımlar ile uyumlu matematiksel modelleme problemlerine rastlanmamıştır. Bu çalışma ile finansal bağlamda matematiksel modelleme problemlerinin tasarlanması amaçlanmıştır. $\mathrm{Bu}$ aşamalarda ortaya çıkan veriler açıkça ortaya konarak farklılıklar belirlenmiş ve matematiksel modelleme problemleri hazırlama tasarım önerisi şeması ortaya konmuştur. Araştırmada finansal içerikte hazırlanan matematiksel modelleme problemleri üç aşamadan geçilerek hazırlanmıştır. Birinci aşama ön uygulamanın yapılması aşamasıdır. İkinci aşamada finans konusunda uzman kişilerden görüş alınmıştır. Son aşamada ise matematik eğitimi konusunda uzman kişilerden görüş alınmıştır (Şekil 1). Bu aşamaların her biri araştırmacıya sorunun düzenlemesi için farklı perspektifler sunmuştur. Verilere göre matematiksel modelleme problemleri son halini almıştır.

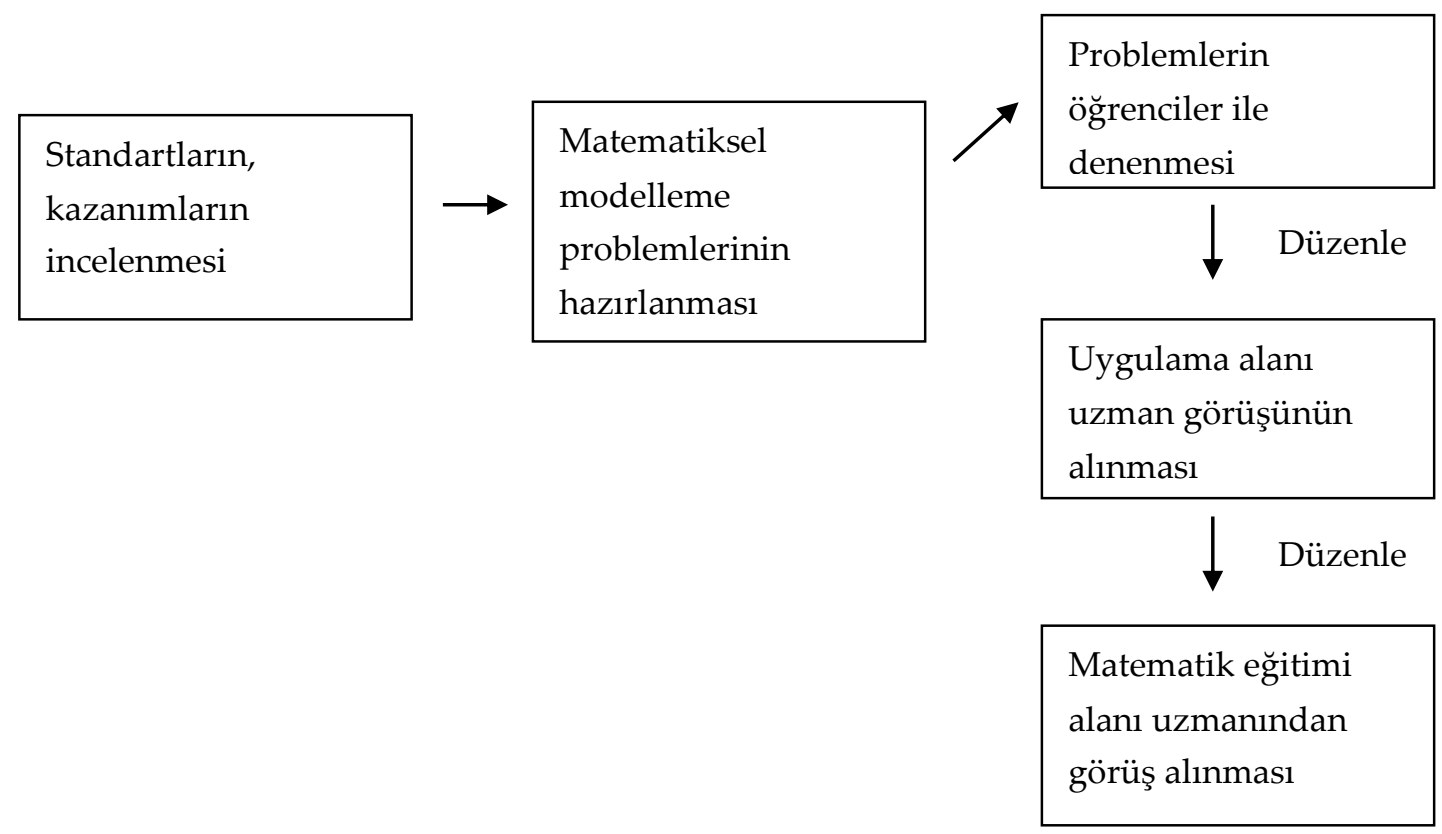

Şekil 4: Uygulanan aşamaların şeması

Üç yedinci sınıf öğrencisi ile yapılan ön uygulama; hazırlanan matematiksel modelleme problemlerinin yedinci sınıf öğrenci seviyesine uygunluğu, zamanlama, problemlerin anlaşılırlığı ve öğrencilerin bağlam hakkındaki ön bilgileri konusunda değerlendirmeler sunmuştur. Uygulama alanındaki uzmanlar finansal eğitim standartlarında belirtilen kazanımlara uygunluk konusunda görüş bildirmişleridir. $\mathrm{Bu}$ görüşler aynı zamanda matematiksel modelleme prensiplerinden gerçeklik ilkesi ile ilgili önemli bilgiler sunmuştur. Alan eğitimcilerinden ise model oluşturma problemlerinin 
öğrenme prensiplerine uygun olması konusunda dönütler elde edilmesi sağlanmıştır. Matematik eğitimi alan uzmanları modelleme prensiplerinden en çok gerçeklik prensibini önemsemişlerdir. Alan uzmanları aynı zamanda problemlerin sınıf seviyesine ve matematik kazanımlarına uygunluğu konusunda da görüş bildirmişlerdir. Araştırmada elde edilen nitel veriler problemlerin tasarlanmasında yol gösterici olmuştur. Örneğin finans alan uzmanlarından biri bisiklet etkinliğinde tabloda verilen ürünler arasında bisiklet yapımında kullanılan malzemelerin bulunması önermiştir. Bu öneri üzerine fiyatı verilen ürünlere lastik ve jant fiyatının eklenmesine karar verilmiştir.

Tasarım tabanlı araştırmalarda ise yapılan tasarımın çalışıp çalışmadığının belirlenmesi için çok sayıda bağımlı değişken üzerindeki etkisini incelemek gerekir ve ortamdaki bağımlı değişken sayısı çok fazla olduğu durumlarda araştırmacılar önem durumuna göre bazı bağımlı değişkenleri göz ardı etmek durumunda kalabilirler (Kuzu, Çankaya, Mısırlı, 2011). Bu çalışmada kimi zaman birinci, ikinci ve üçüncü aşamada elde edilen veriler problemin geliştirilmesinde çelişkiler oluşturmuştur. $\mathrm{Bu}$ durumda düzenlemeler çok boyutlu değerlendirmeler sonucunda yapılmıştır. Örneğin "Meyve bahçesi" etkinliğinde gerçek hayatla uyumlu olması açısından bahçenin alanı dönüm cinsinden sorulmuştu. Problemin gerçeklik ve model oluşturma prensiplerine uygunluğunun geliştirilmesi üzerine görüş bildiren alan uzmanlarından biri “bir kenarı 40 metre olan" ifadesi yerine "1,6 dönüm" ifadesinin daha uygun olacağını belirtmiştir. Fakat ön uygulama esnasında öğrenciler karenin alanından karenin kenarını hesaplamakta güçlük çekmişlerdir. Bu nedenle kare şeklindeki tarlanın alanı yerine bir kenar uzunluğunun verilmesi uygun görülmüştür.

Çalışmada problemlerin düzenlenmesi tüm aşamalar bittikten sonra uygulanmıştır. Bu durum araştırmacıya bazı zorluklar oluşturmuştur. Örneğin ön uygulamanın ardından yapılan değişikliklerin uzmanlar tarafından yorumlanmasına ihtiyaç duyulmuştur. Bu çalışmadan "geliştirilmeli" şeklinde görüş bildiren uzmanların fikirlerini dikkate alarak uzlaşı sağlanması ve değişikliklerin yapılmasının ardından matematik eğitimi alanında uzman bir öğretmen ve öğretim üyesinden oluşan bir geçerlik komitesi oluşturulmuştur. Uzman görüşünü döngüsel olarak almak karmaşa yaratmakta ve zaman almaktadır. Bu nedenle bu araştırmada bu aşamaların sıralamasının önemi ortaya çıkmaktadır. Aşamaların sıralanmasında ön uygulamanın ilk önce yapılarak ardından uzman görüşüne sunulması sorunun geliştirilmesine daha çok katkı sağlamaktadır. Örneğin bisiklet etkinliğinde ön uygulamada aşamasında öğrenciler ürün fiyatı ile parça fiyatı arasında ilişkilendirme yapmışlardır. Öğrenci ifadesi şu şekildedir: "Bisiklet bir spor aletidir, verilerde spor aletinin yüzdesi ne kadar arttıysa o kadar artıralım". Öğrencinin gruptaki bu önerisi üzerine 
problemde verilen ürün fiyatlarına birkaç spor aletinin fiyatı daha eklenerek problem geliştirilmiştir. Bu durumun ardından tekrar uzman görüşüne sunma ihtiyacı hissedilmiştir.

Matematiksel modelleme problemleri yaşantıyla ilişkili gerçekçi bağlamlardan oluşmalıdır (Gravemeijer, 1999). Bu nedenle matematiksel modelleme problemlerinin oluşturulmasında uygulama alanı uzmanı görüşü almak etkinliğin bilimsel anlamda doğru hazırlanmasını sağlayabilmektedir. Uygulama alanı uzmanı, matematik eğitimi alan uzmanın tahmin edemediği durumlarda problemin geliştirilmesine yönelik geri dönüt sağlayabilmektedir. Buna örnek durum "Birikimini değerlendir" etkinliğinde oluşmuştur. $\mathrm{Bu}$ problemle ilgili bir finans alanı uzmanı problemin geliştirilebileceği konusunda görüş bildirmiş, “Hale'nin parası 2015 yılı sonunda en fazla ne kadar olurdu?" problemin hesaplanmasının içeriğe ve finansal kazanıma uygun olmadığı belirtilmiştir. Konuya ilişkin görüş şu şekilde belirtilmiştir: "Paranın değerlendirilmesi için seçenek çok fazla. Tabloda yer alan dört alternatiften sadece birine yatırabilir veya parasını bu alternatifler arasında bölüştürerek sepet yapabilir. Dolayısıyla bu sorunun cevabı için çok fazla alternatif hesaplanması gerekir." Matematik alan uzmanı "Birikimini değerlendir" matematiksel modelleme probleminin modelleme ilkelerine uygunluğunun geliştirilebileceğini belirtmiştir. Öneride tek çözüm üzerinde durulmuştur. Uzman ifadesi şu şekildedir: "Sorunun çözümünde tek çözüm var." Oysa bu bağlamda finans uzmanın da belirttiği gibi problemin birçok çözümü bulunmaktadır. Öğrencilerin riski yönetebilmek gibi finansal bilgilerini de kullanarak, bu ihtimalleri öngörebilmeleri önemsenmektedir. Modelleme problemlerinin alternatif çözümler içerebilmesi durumu düşünüldüğünde çözüm alternatiflerini öğrencilerin tartışı yorumlaması açısından uygun bir problem olduğu düşünülmüştür. Bu nedenle eleştiri üzerine bir düzenleme yapılmamıştır. Finans uzmanının görüşü dikkate alınarak problem kökü üzerinde düzenlenme yapılmıştır. Bu nedenle Şekil 4 de belirtildiği gibi uzman görüşünün önceliklendirilmesinde ilk önce uygulama alanı uzmanına danışmak soruyu daha geliştirici olacaktır.

Bu çalışma ile ön uygulama ve uzman görüşün önceliklendirilmesine yönelik tasarım rehberi şu şekilde oluşturulmuştur. 


\begin{tabular}{|c|c|}
\hline $\begin{array}{l}\text { Standartların, } \\
\text { kazanımların } \\
\text { incelenmesi }\end{array}$ & $\begin{array}{l}\text { Matematiksel } \\
\text { modelleme } \\
\text { problemlerinin } \\
\text { hazırlanması }\end{array}$ \\
\hline
\end{tabular}

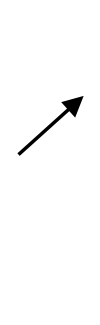

Problemlerin

öğrenciler ile

denenmesi

Düzenle

$$
\begin{aligned}
& \text { Uygulama alanı } \\
& \text { uzman görüşünün } \\
& \text { alınması }
\end{aligned}
$$

Düzenle

Matematik eğitimi

alanı uzmanından

görüş alınması

Şekil 5. Uzman görüsü önceliklendirmesi

Matematiksel modelleme sürecinin döngü içeren bir süreç olduğu fikri, modelleme yaklaşımlarında ortak fikir olarak karşımıza çıkmaktadır (Zbiek \& Conner, 2006). Lakin matematiksel modelleme problemlerinin hazırlanmasında döngüsel bir süreç vurgulanmamaktadır. Literatürde yer alan öğretmenlerin ve öğretmen adaylarının hazırladıkları matematiksel modelleme soruların değerlendirilmesi modelleme prensiplerine uygunluk açısından yapılmaktadır. Bu çalışmada matematiksel modelleme sorularının hazırlanması sürecine öğrencilerin bu soruları çözüm süreci verileri ve uygulama alan uzmanı görüşleri de dahil edilmiştir. Matematiksel modelleme problemlerinin hazırlanmasında Şekil 5'deki öncelikte hazırlanması zaman ve analiz açısından kolaylık sağlayacak niteliktedir. Bu şemadan faydalanılarak ileriki çalışmalarda farklı bağlamlarda ve farklı sınıf seviyeleri için matematiksel modelleme problemleri tasarlanabilir.

\section{Kaynaklar}

Aztekin, S. \& Şener, Z.T. (2015). The content analysis of mathematical modelling studies in turkey: a meta-synthesis study. Education and Science, 40 (178).

Bernheim, D., Garrettand D., \& Maki D., (2001). Education and saving: The long-term effects of high school financial curriculum mandates. Journal of Public Economics, 85, 435-565.

Berry, J. \& Houston, K. (1995) Students using posters as a means of communication and assessment. Educational Studies in Mathematics, 29(1), 21-27 Published by: Springer Stable URL: http://www.jstor.org/stable/3482829.

Blomhøj, M. \& Jensen, T. H. (2003). Developing mathematical modelling competence: conceptual clarification and educational planning. Teaching Mathematics and Its Applications, 22(3), 123-139 
Carlson, M., Larsen, S., \& Lesh, R. (2003). Integrating models and modeling perspective with existing research and practice. In R. Lesh \& H. M. Doerr (Eds.), Beyond constructivism: Models and modelling perspective on mathematics problem solving, learning, and teaching (pp. 465-478). Mahwah, NJ: Lawrence Erlbaum.

Cobb, P., Confrey, J., diSessa, A., Lehrer, R. ve Schauble, L. (2003). Design experiments in educational research. Educational Researcher, 32(1), 9-13.

Cole, S., T. \& Sampsonand B. Z. (2011). Pricesor knowledge? What drives demand for financial services in emerging markets?. The Journal of Finance, 66(6),1933-1967.

Creswell, J. W. (2003). Research design: qualitative, quantitative, and mixed method approaches. Thousand Oaks, Calif, Sage Publications.

Crouch, R., \& Haines, C. (2004). Mathematical modelling: Transitions between the real world and mathematical model. International Journal of Mathematical Education in Science and Technology, 35(2), 197-206.

Gravemeijer, K. (1999). Emergent models may foster the constitution of formal mathematics. Mathematical Thinking and Learning, 1(2), 155-177.

Greer, B. (1993). The mathematical modelling perspective on world problems. Journal of Mathematical Behaviour, 12, 239-250.

Haines, C. \& Crouch, R. (2001). Recognising constructs within mathematical modelling. Teaching Mathematics and its Applications, 20(3), 129-138.

Haines, C., Crouch, R., \& Davis, J. (2000). Mathematical modelling skills: A research instrument (Technical Report No. 55). Hatfield, UK: University of Hertfordshire, Department of Mathematics

INFE. (2009). Financial education programmes in schools: draft comparative analysis of selected financial education learning frameworks: International network on financial education.

Jensen, T. H. (2007). Assessing mathematical modelling competency. In C. Haines, P. Galbraith, W. Blum and S. Khan (Eds.), Mathematical Modelling Education, Engineering and Economics (ICTMA12). pp. 141-148. Chichester: Horwood.

Kuzu, A.,Çankaya, S., Mısırlı, Z. A. (2011). Tasarım tabanlı araştırma ve öğrenme ortamlarının tasarımı ve geliştirilmesinde kullanımı. Anadolu Journal of Educational Sciences International, 1(1).

Lawshe, C. H. (1975). A quantitative approach to content validity. Personnel Psychology, 28, 563-575.

Lesh , R.A., \& Doerr, H. (2003). Foundations of model and modeling perspectives on mathematic teaching and learning. In R.A. Lesh and H. Doerr (Eds.), Beyond constructivism: A models and modeling perspectives on mathematics teaching, learning, and problem solving. Mahwah, NJ: Lawrance Erlbaum.

Lusardi, A. (2009), U.S. Household savings behavior: the role of financial literacy, information and financial education programs, InC. Foote, L. Goetteand S. Meier (eds.), Policy making Insights from Behavioral Economics, Federal Reserve Bank of Boston, pp. 109149. 
Milli Eğitim Bakanlığı. (2009). İlköğretim matematik dersi 6-8. sinıflar öğretim programı ve kılavuzu, Ankara: Yazar.

Merriam, S. B. (1998). Qualitative researchand case study applications in education (second edition). San Francisco: Jossey-BassPublishers

Miles MB, Huberman M. (1994). Qualitative data analysis: a sourcebook of new methods. 2. Beverly Hills, CA: Sage Publications

Niss, M. \& Jensen, T. H. (eds) (2002). Kompetencer og matematiklæring - Ideer og inspiration til udvikling af matematikundervisning i Danmark, number 18 in Uddannelsesstyrelsens temahæfteserie, The Ministry of Education, Copenhagen, Denmark. Cf. http://nyfaglighed.emu.dk/kom.

OECD (2005), Improving financial literacy analysis of issue and policies, PISA, OECD Publishing.

OECD (2012), Guidelines on financial education at school and guidance on learning framework, PISA, OECD Publishing.

Schoenfeld, A. H. (1982). Some thoughts on problem-solving research and mathematics education. In F. K. Lester And J. Garofalo (Eds.) Mathematical problem solving: issues in research (Pp. 27-37). Philadelphia: Franklin Institute Press.

Veneziano L. \& Hooper J. (1997). A method for quantifying content validity of health-related questionnaires. American Journal of Health Behavior, 21(1),67-70.

Wang, F. \& Hannafin, M. (2005). Design-based research and technology-enhanced learning environments. Educational Technology Research and Development, 53(4), 5-23.

Yurdugül, H. (2005). Ölçek geliştirme çalışmalarında kapsam geçerliği için kapsam geçerlik indekslerinin kullanılması. XIV. Eğitim Bilimleri Kurultayı, 28-30 Eylül, Pamukkale Üniversitesi, Denizli

Zbiek, R. M. \& Conner, A. (2006). Beyond motivation: exploring mathematical modelling as a context for deepening students' understandings of curricular mathematics. Educational Studies in Mathematics, 63, 89-112. 